\title{
Assessing and Teaching Critical Thinking in Communication Science and Disorders
}

\author{
Richard J. Morris \\ Florida State University, rmorris@fsu.edu \\ Mary M. Gorham-Rowan \\ Valdosta State University, mmgorhamrowan@valdosta.edu \\ Jade H. Robinson Ph.D. \\ Valdosta State University, jade.robinson@eku.edu
}

See next page for additional authors

DOI: doi.org/10.30707/TLCSD2.1Morris

Follow this and additional works at: https://ir.library.illinoisstate.edu/tlcsd

Part of the Communication Sciences and Disorders Commons

\section{Recommended Citation}

Morris, Richard J.; Gorham-Rowan, Mary M.; Robinson, Jade H. Ph.D.; and Scholz, Kendra (2018) "Assessing and Teaching Critical Thinking in Communication Science and Disorders," Teaching and Learning in Communication Sciences \& Disorders: Vol. 2: Iss. 1, Article 4.

DOI: doi.org/10.30707/TLCSD2.1Morris

Available at: https://ir.library.illinoisstate.edu/tlcsd/vol2/iss1/4

This Reflection on SoTL is brought to you for free and open access by ISU ReD: Research and eData. It has been accepted for inclusion in Teaching and Learning in Communication Sciences \& Disorders by an authorized editor of ISU ReD: Research and eData. For more information, please contact ISUReD@ilstu.edu. 


\title{
Assessing and Teaching Critical Thinking in Communication Science and Disorders
}

\begin{abstract}
Critical thinking is considered to be an important aspect in the training of communication science and disorders students. This paper provides information on the definition, assessment, and teaching of critical thinking. Important critical thinking skills and dispositions include challenging assumptions underlying statements, recognizing the effect of context on perceptions, understandings, and interpretations of the world, developing alternative explanations for observed data they observe, and exhibiting reflective skepticism. Increasing these skills and dispositions help a student develop into a skilled clinician. Assessing students' clinical thinking skills can be done with tests of general skills, but these often lack validity and reliability. Assessments also can test content or discipline specific thinking skills. Teaching critical skills and dispositions has been done in stand-alone courses and as material embedded within other courses. Within the courses, techniques such as problem-based learning, team-based learning, and case presentations have been effective with mind and concept mapping as tools to visualize how the students think about the material.
\end{abstract}

\section{Keywords}

critical thinking, critical thinking assessment, critical thinking teaching

\section{Cover Page Footnote}

Portions of this manuscript were presented at the 2014 Annual Convention of the American SpeechLanguage-Hearing Association

\section{Authors}

Richard J. Morris, Mary M. Gorham-Rowan, Jade H. Robinson Ph.D., and Kendra Scholz 
One of the foundations of clinical practice in speech-language pathology (SLP) and audiology (AUD) is that the practitioners critically review the relevant research that underlies their evaluations and treatments (Orlikoff, Schiavetti, \& Metz, 2015). Orlikoff et al. said that communication science and disorders (CSD) clinicians need to decide whether claims about evaluation and treatment techniques actually align with research outcomes by critically reading the research. In this manner these authors connect critical reading to critical thinking, a skill that they state is fundamental to clinical practice. The level of critical thinking among university students has been discussed since Bloom and colleagues stated that college students were developing inadequate thinking skills (Bloom, Engelhart, Furst, Hill \& Krathwohl, 1956).

Recently, Arum and Roksa (2011) reported that only 64\% of the college graduates in their study exhibited significant improvements in their critical thinking skills as a result of their college education. These data indicate little change in the critical thinking skills of the college students as a result of their education. In addition, the United States Department of Education (USDOE) (2006) reported concerns about declining quality of university student learning in terms of critical thinking, writing, and problem solving. If the USDOE data accurately represent trends in college graduate thinking skills, then an increasing proportion of college graduates may engage in thinking errors. Kida (2006) stated that some of the common thinking errors include: believing stories over statistics (preferring to believe narratives rather than numbers), confirmation bias (preferring and maintaining personal or preexisting beliefs despite evidence that they are incorrect), oversimplification (using heuristics or simplifying strategies for complex issues that might ignore relevant information), misperception (perceiving what we expect and believing the perception is accurate), memory errors (believing our memories are accurate and unchangeable when they are neither), and assuming causality (believing that two events are causally related when the relationship between the events could be correlation or coincidence). These errors often occur when people attempt to make decisions or solve problems efficiently. To explain this process Green (2015) stated that the human brain works to operate in the most energy efficient manner, the manner that requires the least amount of cognitive work. Green continued by saying that better decision making and problem solving occurs when reflective, critical, or skeptical reasoning are used, and those thinking strategies involve more cognitive work. In order to train the most effective clinicians, faculty members in CSD programs should work to help their students develop the disposition to regularly use higher order critical thinking skills. Clinical practices in CSD require the habit of using reflective, critical, or skeptical reasoning skills consistently when evaluating and treating clients (Gunter \& LeJeune, 2015; Orlikoff et al., 2015). 
Kamhi (2011) addressed the thinking skills required for the practice of speech language pathology when he discussed the interplay between evidence-based practices and the scientific method. He discussed the tension between the certainty one might have about a clinical technique and skepticism about the effectiveness of the technique, particularly when evidence-based practice methods had been used to select the technique. He wrote that skepticism concerning use of a clinical technique is an essential component of scientific thinking. Clinicians need to be able to question their selected clinical techniques and ask themselves whether there may be a better choice. The certainty that some clinicians maintain for their favored treatment techniques could result from faulty thinking patterns such as those listed above from Kida (2006). Kamhi (2011) noted that clinicians need to question and be skeptical so that they explore the best practices when treating clients. He reminded readers that Dollaghan (2007) considered uncertainty concerning the effectiveness of treatment techniques to be a precondition for clinicians to use evidence-based practice. Kamhi (2011) concluded that "although clinical practice may include some of the principles and methods of science, it will always fall short of being truly scientific because it has no intrinsic mechanism for independent evaluation and verification." (p. 61).

Apel (2011) responded to Kamhi's claim by stating that clinicians evaluate and verify their clinical techniques through client communication improvements and reimbursement by insurance companies. Clinicians maximize positive clinical outcomes when they develop and use critical thinking skills so that they are skeptical of the efficacy of the treatment techniques they use. In this manner clinicians can test their techniques by regularly verifying the data and the reactions of their clients in order to achieve the balance Kamhi (2011) discussed between the certainty that they can effectively help their clients and the uncertainty that their treatment techniques are the most effective. As noted by Apel (2011), changes in client behavior can reinforce the certainty that the current clinical techniques are effective, and in contrast, the absence of and/or limited behavioral change indicate the need for skepticism concerning the treatment technique being used.

In a separate response to Kamhi's article, Finn (2011) highlighted the importance of critical thinking to the development of clinical skills in CSD students. He discussed the core skills that CSD students need for more effective thinking about clinical practices; these skills include interpretation, evaluation, and metacognition.

- Interpretation included three components: identifying the assertion, such as "this is the best treatment for your client;" determining the reasons and literature sources that support the assertion, such as research data or clinical 
experience; and assessing the assertion for poorly defined terms and underlying assumptions.

- Evaluation requires that students determine the acceptability of the assertion by assessing the credibility of the statements supporting it. This assessment includes both the credibility of the source of the statements, such as the author(s), website, publication, etc., and the quality and quantity of data that form the basis of the statements. This evaluation process helps the student decide whether to agree with the assertion or to consider other alternatives.

- Metacognition requires the student to analyze her thinking strategies and operations when interpreting and evaluating the assertion. This activity includes three aspects: level of understanding of the assertion, internal assumptions about the assertion, and monitoring of thinking strategies to keep the student's thinking clear and rational. These aspects indicate the need for self-reflection in order for the student to be aware of the extent to which she understands an assertion and all of the terms related to it, the underlying assumptions associated with the assertion, and continuous monitoring of the student's thinking strategies.

Finn (2011) then stated that in order for CSD students to develop these critical thinking skills and attributes, they need to be included among the goals of CSD programs engaged in clinician preparation. Accordingly, CSD program faculty members need a plan for assessing and teaching these skills and attributes. That plan should be based in the growing body of research on these topics. However, critical thinking researchers express differing opinions on what methods are effective for assessing and teaching these skills and dispositions. Some of these perspectives on assessing and teaching critical thinking comprise the following sections.

\section{Assessing Critical Thinking}

The definition, assessment, and instruction of critical thinking skills are all intricately interwoven. In general, two perspectives of critical thinking assessment and instruction prevail. Some consider these skills as generic abilities that apply across different content areas as a thinking framework (Davies, 2013; Ennis, 1989), whereas others state that all thinking is about a specific topic and these thinking skills are used in the context of the specific content (Beyer, 1987; McPeck, 1981). When authors describe critical thinking skills as generic thinking skills, they mean that the skills are basic cognitive skills that apply equally to any area of thought or study. Since students use critical thinking skills within specified areas of thought 
and use the same skills and dispositions independent of the specific topic, these skills and dispositions can be taught in stand-alone courses without concern as to the content used to develop them (Royalty, 1995; Sá, West, \& Stanovich, 1999). In contrast, other authors say that these skills are subject- or content-dependent and that critical thinking skills are best learned as a component of courses centered on content pertinent to the students' academic interests (Halliday, 2000; Smith, 2002). The second group of authors stated that all thinking is about something and that the topic of the thinking is an important part of the learning. They believe that learning critical thinking skills and dispositions requires thinking about a topic that the student already understands. However, Davies (2013) argued that the topic centered approach to critical thinking makes the underlying critical thinking concepts relativistic and affects the students' ability to generate a consistent set of definitions for them. Presently there is insufficient evidence to clearly establish one position or the other as generally correct. It is clear is that the two constructs of critical thinking lead to separate types of instruments for assessing these skills.

Generic Skills Critical Thinking Assessment Instruments. A variety of instruments have been developed to assess critical thinking skills as generic skills. Several of them and some of their characteristics are displayed in Table 1. These instruments use response formats that include multiple choice selections, Likertscale ratings, short answer essays, and combinations of open ended and forced choice responses (e.g., Ennis \& Weir, 1985; Facione, 1990; Halpern, 2010; Stein \& Haynes, 2011; Wagner \& Harvey, 2006). Several of the critical thinking assessment tools such as the Cornell Critical Thinking Test (Ennis \& Millman, 1985), the California Critical Thinking Disposition Inventory (Facione, Facione, \& Giancarlo, 1996), the California Critical Thinking Skills Test (Facione, 1990), and the Watson-Glaser Critical Thinking Appraisal (Watson \& Glaser, 1980) have been standardized using college student samples. However, a meta-analysis of these generic skills tests indicated that these assessments exhibit inconsistent reliability and validity (Abrami et al., 2008).

One exception to this problem occurred for the overall score of the Watson-Glaser Critical Thinking Appraisal. Meta-analyses revealed that the overall score for this assessment had high validity for the comparison between student course achievement and their critical thinking skill development (Bernard, Zhang, Abrami, Sicoly, Borokhovski, \& Surkes, 2008; Burke, Sears, Kraus, \& Roberts-Cady, 2013). However, when Bernard and colleagues (2008) examined the correlations between the subsection scores of this critical thinking assessment and either student course achievement or critical thinking skills, they reported lower associations. These differing results from the same assessment constrain the sense that the 
Table 1. Characteristics of several general skills critical thinking assessments.

Test Name

ACT Collegiate Assessment of Academic

Proficiency-Critical Thinking Test

http://www.act.org/caap/tests/thinking.html

California Critical Thinking Disposition Inventory http://www.insightassessment.com/test-cctdi.html

California Critical Thinking Skills Test

http://www.insightassessment.com/test-cctst.html

Collegiate Learning Assessment
http://www.cae.org/default.asp

Collegiate Learning Assessment

http://www.cae.org/default.asp

Cornell Critical Thinking Test

http://www.criticalthinking.com/cornell-critical-

thinking-tests.html

Critical Thinking Assessment Test

https://www.tntech.edu/cat/

Ennis-Weir Critical Thinking Essay Test

http://faculty.education.illinois.edu/rhennis/tewctet

/Ennis-Weir_Merged.pdf

\section{Response Type \\ multiple choice}

Likert scale:

extent of

agreement with

prompts

multiple choice

45

Length

(minutes)

Technology

paper/pencil

Strengths

Broad psychometrics

Weaknesses

Question design

30

online;

paper/pencil

Broad psychometrics

online;

paper/pencil

Broad psychometrics

short answer

multiple choice

60

online

30

online

multiple choice

50

computer;

paper/pencil

short answer

60

paper/pencil

short answer

40

paper/pencil
Thought patterns

High reliability,

Broad psychometrics

Broad psychometrics

Good external patterns

Moderate external validity, Thought patterns validity, Thought
Inconsistent reliability and validity

Forms not comparable, Inconsistent reliability and validity

Weak reliability

Expensive

Inconsistent reliability and validity, Question design 
Teaching and Learning in Communication Sciences \& Disorders, Vol. 2 [2018], Iss. 1, Art. 4

\author{
Test Name \\ Halpern Critical Thinking Assessment \\ http://lafayetteevaluation.com/products/halpern- \\ thinking-50admin \\ International Critical Thinking Essay Test \\ https://www.criticalthinking.org/store/products/int \\ ernational-critical-thinking-essay-test/185 \\ Watson-Glaser Critical Thinking Appraisal \\ https://www.criticalthinking.org/store/products/int \\ ernational-critical-thinking-essay-test/185
}

\begin{tabular}{|c|c|c|c|c|}
\hline $\begin{array}{l}\text { Response Type } \\
\text { multiple choice, } \\
\text { forced choice } \\
\text { (ranking, rating) }\end{array}$ & $\begin{array}{c}\begin{array}{c}\text { Length } \\
\text { (minutes) }\end{array} \\
60-80\end{array}$ & $\frac{\text { Technology }}{\text { computer }}$ & $\begin{array}{l}\text { Strengths } \\
\text { Good external } \\
\text { validity, Broad } \\
\text { psychometrics }\end{array}$ & $\underline{\text { Weaknesses }}$ \\
\hline short answer & 50 & paper/pencil & $\begin{array}{l}\text { High instructional } \\
\text { value, Thought } \\
\text { patterns }\end{array}$ & Expensive \\
\hline multiple choice & $40-60$ & $\begin{array}{l}\text { online; } \\
\text { paper/pencil }\end{array}$ & Broad psychometrics & $\begin{array}{l}\text { Inconsistent } \\
\text { reliability and } \\
\text { validity, } \\
\text { Question design }\end{array}$ \\
\hline
\end{tabular}


Watson-Glaser Critical Thinking Appraisal is a valid measure of critical thinking. The authors of the meta-analyses do not hypothesize about the differences in the relationships or possible underlying causes (Abrami et al., 2008; Bernard et al., 2008). One must conclude that only the overall score from the Watson-Glaser Critical Thinking Appraisal provides an indication of changes in student critical thinking skills. However, the structure of this test may be a factor in the low correlations between the subtests and other measures of student critical thinking skill development.

Possin (2008) provided a rating guide on several of the generic critical thinking assessments. He stated that the California Critical Thinking Disposition Inventory is an opinion survey and provides no data on the use of critical thinking skills. Similarly, he reported problems in the structure of the objective tests such as the Watson-Glaser Critical Thinking Appraisal Test, the Cornell Critical Thinking Test, the California Critical Thinking Skills Test, and the Collegiate Assessment of Academic Proficiency - Critical Thinking Test (ACT Inc., 2000). Problems found in these tests included issues with the writing of the questions, binary response options, a trade-off between the number of multiple choice options and the number of items included in the assessment, and the possibility of multiple correct responses to questions. Possin (2008) reported that assessment essays appear to better indicate the critical thinking skills of students as indicated through their interpretation of arguments and ability to provide reasonable arguments in support of their own assertions. When considering the cost of the assessments he found the International Critical Thinking Test (Paul \& Elder, 2001) and the Collegiate Learning Assessment (Council for Aid to Education, 2004) too expensive, and the Ennis-Weir Critical Thinking Essay Test (Ennis \& Weir, 1985) an effective and affordable tool.

Two recently developed standardized generic skill critical thinking evaluations appear to hold promise to have higher validity and reliability. The developers of the Critical Thinking Assessment Test (CAT) compared student responses from their short answer based critical thinking test and the multiple-choice items of the California Critical Thinking Skills Test (Stein \& Haynes, 2011). Stein, Haynes, and Redding (2007) reported higher correlations for the CAT with critical thinking related items on the National Survey of Student Engagement (NSSE Institute for Effective Educational Practice, Indiana University Center for Postsecondary Research) than for the California Critical Thinking Skills Test. Similarly, the Halpern Critical Thinking Assessment, an assessment comprised of open ended questions, has been shown to predict real world outcomes of critical thinking (Butler, 2012; Butler et al., 2012). These findings and Possin's (2008) guide 
indicate that the short answer format may be a more effective method to assess critical thinking skills. Short answer prompts incorporate the writing component favored by Possin and can specifically address a wider variety of critical thinking skills than is possible in essay style assessments comprised of one or two prompts.

An aspect of the CAT that may help its validity is that the designers train prospective users to reliably administer and score the assessment (Stein \& Haynes, 2011). Stein and Haynes (2011) report high reliability between the scores from trained faculty members and those from CAT experts who grade the same papers. Although this scoring method may not dramatically affect the students' critical thinking scores, it creates a connection between the assessment and the faculty members who administer and score it. This scoring method provides an opportunity for the faculty members to discuss student responses to the critical thinking evaluation and use those discussions to inform their teaching. Since the CAT is a generic skills critical thinking test, the scoring method is not likely to lead to teaching the test as the test items do not match well with the content of any specific course.

Content Centered Critical Thinking Assessment Instruments. In contrast to the generic approach to assessing critical thinking skills, the content centered approach requires assessments that are content specific to best assess student critical thinking skills. These authors state that domain knowledge, or knowledge on the topic, is a component of the thinking skills (Beyer, 1987; McPeck, 1981). The authors of many critical thinking tests indicate the validity of their instruments by correlating them with other indicators of general thinking skills, such as SAT results (Ennis \& Weir, 1985, Facione, 1990; Halpern, 2010, Stein \& Haynes, 2011). However, students may not exhibit the focused effort and strategies required to demonstrate critical thinking skills if they do not perceive that the assessment contains items of interest to them (Macpherson \& Owen, 2010). In particular, Yuan, Liao, Wang, and Chou (2014) questioned the use of general critical thinking assessments when evaluating students in a clinical program. They reported that the clinically oriented students might respond better to questions based on clinical questions relevant to their field of study. Centered around this hypothesis, they developed a clinically based assessment for medical professionals and found their test to be reliable and valid. They stated that the Cronbach's $\alpha$ of their instrument was higher than those reported for the California Critical Thinking Disposition Inventory or the WatsonGlaser Critical Thinking Appraisal. Although Yuan et al.'s (2014) results provide only a single example, they indicate a critical thinking assessment that includes clinically relevant, content specific items may be an effective tool for determining the critical thinking skills of students in clinical programs. 
Recently, Morris, Bishop, Scholz, and LaPointe (submitted) developed the Critical Thinking Test for Communication Sciences and Disorders (CTCSD), a content specific critical thinking assessment. Specific thinking skills evaluated in the CTCSD include causal reasoning, deductive reasoning, and the adequacy and/or quality of data presented to the students. The CTCSD was designed to evaluate many of the same critical thinking skills as the CAT. A preliminary version of the CTCSD was administered to a group of 23 undergraduate students in a CSD program. In addition, these students completed the CAT. The correlation ( $\mathrm{r}=.793$, $\mathrm{p}<.01$ ) of the students' scores on the similar content items of these two instruments is shown in Figure 1. Thus, the CTCSD shows promise to be an effective content specific tool for assessing the critical thinking skills of students in CSD. In addition, the students performed as well or better for 12 of the 14 target critical thinking skills. The improved performance may be a consequence of the CSD students maintaining greater interest in the content that is specific to their major. Clearly, many more students need to be assessed using the CTCSD in order to determine its reliability and validity. Hopefully, the CTCSD can be a useful tool for measuring the pre- and post-training critical thinking skills of CSD students. Another potential use of the CTCSD is to help determine the effectiveness of different pedagogical approaches to teaching critical thinking skills.

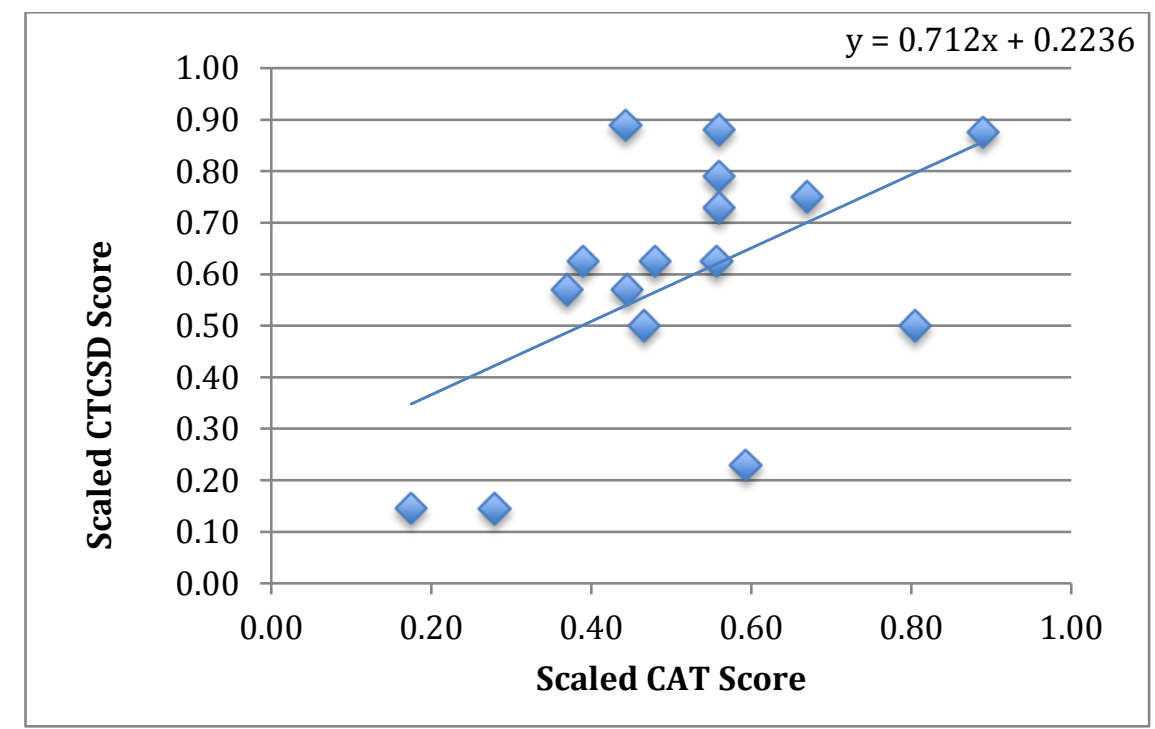

Figure 1. Correlation of CAT with CTCSD

\section{Perspectives on Teaching Critical Thinking Skills}

Since a range of opinions exist concerning the scope and components of critical thinking, faculty members have different conceptual understandings for teaching 
critical thinking. The different conceptualizations of critical thinking result in varying curricular designs and educational approaches within and across disciplines (Thomas \& Lok, 2015). Similar to critical thinking assessment, the methods for teaching critical thinking depend upon the biases of the faculty members teaching the courses. Those who hold a generic skills perspective on critical thinking tend to support stand-alone courses on the topic that explicitly teach the underlying skills and dispositions. In contrast, those who hold a content-based perspective tend to support embedding the critical thinking skills and dispositions into other courses and providing implicit instruction of this content. Abrami et al. (2008) differentiated explicit and implicit instruction as follows:

- Explicit instruction includes teaching the structure and procedures of critical thinking, and critical thinking skills are a course objective.

- Implicit instruction has the critical thinking goals woven into other course content. Thus, the structure and procedures of critical thinking are not taught and critical thinking skills are not a course objective. Essentially, in an implicit setting, developing critical thinking think skills is a desired byproduct of learning the main course content.

Instruction Techniques. From these two instruction methods come four instruction techniques: general, infused, immersed, and mixed (Abrami et al. 2008; Ennis, 1989) (See Table 2). The general technique involves teaching critical thinking abilities separately from any other subject matter. Proponents of this technique believe that teaching critical thinking skills does not require other subject material. When using the infused technique, the instructor uses discipline based material as the foundation for teaching critical thinking about the material and critical thinking goals are still explicitly taught. The immersion approach includes the same teaching structure as the infused method except that the critical thinking goals are not explicitly taught. Finally, when using the mixed technique, the instructor combines the general technique and either the immersion or infused technique. Thus, the critical thinking skills are taught in the context of course content material as well as through explicit critical thinking instruction that is not coupled with the other content (Abrami et al., 2008).

Table 2. Techniques for teaching critical thinking skills and how those techniques are applied in the classroom.

\begin{tabular}{|l|l|}
\hline $\begin{array}{c}\text { Instruction } \\
\text { Technique }\end{array}$ & \multicolumn{1}{|c|}{ Application } \\
\hline General & $\begin{array}{l}\text { Explicit. Critical thinking dispositions and skills taught as content } \\
\text { of course. These dispositions and skills are course goals. }\end{array}$ \\
\hline
\end{tabular}




\begin{tabular}{|c|l|}
\hline Infused & $\begin{array}{l}\text { Explicit. Critical thinking dispositions and skills taught in the } \\
\text { context of discipline specific course content. These dispositions and } \\
\text { skills are course goals. }\end{array}$ \\
\hline Immersion & $\begin{array}{l}\text { Implicit. Critical thinking dispositions and skills taught implicitly } \\
\text { as tools for understanding discipline specific course content. These } \\
\text { dispositions and skills are not course goals. }\end{array}$ \\
\hline Mixed & $\begin{array}{l}\text { Explicit. A combination of the general and either the infused or } \\
\text { immersed instruction techniques. The critical thinking dispositions } \\
\text { and skills are course goals. }\end{array}$ \\
\hline
\end{tabular}

According to results from the meta-analysis by Abrami et al. (2008), using the mixed method of instruction resulted in the greatest critical thinking improvement, while using the immersion method of instruction resulted in the smallest improvement. This finding is in agreement with previous reports that explicit methods of critical thinking instruction resulted in greater improvements in critical thinking ability (Beyer,1987; Burke, et al., 2013). These findings also concur with those of Grillo, Koenig, Gunter, and Kim (2015), who found no change in critical thinking ability among speech-language pathology graduate students after a year of an immersion program. Another interesting quality of the mixed method is the use of both discipline based content with and separate teaching of critical thinking dispositions and skills. The mixed method outperformed both the general method, which relied solely on critical thinking as the content, and the immersion method, which relied solely on using discipline based content. The implication is that neither the strictly explicit nor strictly implicit technique is sufficient for teaching critical thinking. Instead, these results suggest that critical thinking instruction is most effective when it is presented both independently and also within the context of other subject matter. This conclusion supports Davies and Barrett's (2015) statement that the contrast of general and context-dependent techniques for teaching critical thinking skills and dispositions is a false dichotomy since critical thinking skills are revealed through the content and context used to teach them.

Davies (2013) described the development of critical thinking skills as having a triangular shape with the generic skills as the required base upon which to learn the content specific skills at the apex. He stated that the generic skills include the recognition of argument structure: understanding the concepts of truth, validity, soundness, and fallacy; and separating statements, conclusions, and premises from each other. These unsupported assertions agree with the data reported by Abrami et al. (2015). The skills listed by Davies (2013) build upon those provided by Beyer (1987) that included separating relevant from irrelevant information, developing a structure for problem solving, and developing a structure for concept development. 
Thus, there are several skills students need to accumulate and have the disposition to use.

The disposition to use critical thinking skills develops through repeated use of them. Well-designed pedagogical methods provide students the opportunity to develop and repeatedly use the skills so that they have confidence that the skills will be effective. When the teaching of critical thinking includes both general thinking skills and content specific ones, the students can develop the disposition to use critical thinking in any relevant context. For example, applying the knowledge of general critical thinking skills to discipline specific issues allows the student to explore the fallible nature of the conceptual structures within the discipline. Through these experiences, students can perceive that they can use critical thinking approaches from one discipline to solve problems within another discipline (Jones, 2015).

Effective teaching critical thinking dispositions and skills also includes the training of the individual providing the instruction and that person's ability to effectively use that training. Instructors who had received previous training on how to teach critical thinking material were found to be more effective teachers of the mixed method of instruction (Abrami et al., 2008). The degree and type of training are not specified, which necessitates further research on the topic, but the evidence highlights the importance of the role of the instructor's training and skill in order to effectively teach critical thinking skills to students.

Critical Thinking Skills Pedagogy. A combination of critical thinking skills, knowledge, and disposition are needed for students to become effective users of critical thinking. Thomas and Lok (2015) said that skill and knowledge acquisition are necessary, but not sufficient for evaluative reasoning and metacognition; the students must develop the disposition to use the skill and knowledge consistently. They said that practicing critical thinking requires developing skills and attributes over time and that students need to engage in well-reasoned, purposeful activity to put the skills and knowledge into action. Students need classroom opportunities to analyze their own perspectives on controversial issues within their discipline, review the decision process that they use, and test those perspectives through discussions with other students. Such exchanges, along with reflecting on their decision-making, provide students with opportunities to exhibit critical thinking dispositions (Bell \& Loon, 2015). The discussion should be based on a thorough, reasoned evaluation of the available evidence and perspectives provided by writers in the discipline (Bailin \& Battersby, 2015). These reports indicate that students need course based opportunities for the following activities:

- to accumulate source materials on a topic 
- develop data-based opinions

- discuss those opinions with their classmates

- report on what they learned through the process

- indicate how they might improve their process the next time

Teachers need to appreciate that defining, assessing, and teaching critical thinking skills are tasks that must be undertaken, but cannot be completed (Wendland, Robinson, \& Williams, 2015). Wendland and colleagues (2015) said that utilizing critical thinking strategies provides an opportunity for students to question extant systems and existing forms of knowledge, as well as encouraging alternative perspectives. This is the same type of questioning that is needed for clinical practice to be more scientific (Kamhi, 2011; Orlikoff et al., 2015). Thus, these skills and dispositions will help students develop into more effective clinicians.

Maximizing the effectiveness of pedagogical activities requires a clear hierarchical structure. The activities need to help the students move from the routine activities for which they have well-developed skills, to training or experience based activities for which they know the rules, to novel activities that require them to use their thinking skills and knowledge (Thomas \& Lok, 2015). Repeated engagement in novel activities allows the students to develop through the following progression so that they can have a reasoned opinion on the issue while remaining open to the perspectives of others (Byrnes \& Dunbar, 2014; Wendland, et al., 2015).

- Initially accepting the 'expert' opinion as received knowledge,

- Having an awareness of multiple perspectives but having difficulty discerning some of the differences among them,

- Appreciating the differing quality of information and data supporting different positions.

To proceed through the above stated progression, Bailin and Battersby (2015) suggested the following structure for inquiry. First, there should be a clear indication of the issue with key concepts operationally defined. Then, there needs to be recognition of the various assertions and statements about the issue from all perspectives. These assertions and statements need to be assessed as to whether they are factual, evaluative, or interpretive. Next, the student needs to recognize how the assertions and statements are developed into reasons and arguments for the different perspectives. Following that, the student needs to determine the context of the issue as it relates to current practices, the history of the issue, and the social context. Finally, the student needs to evaluate the arguments individually for their factual claims, credibility of sources, quality of arguments, and fallacies, and then make a comparative evaluation as to the quality and quantity of the arguments. 
Given the ongoing nature of the pedagogical task, the repeated opportunity to engage critical thinking skills requires more than a one-semester critical thinking course. Once students learn foundational critical thinking skills and knowledge, they need sufficient repetitions across the curriculum so that they develop the propensity to use the abilities when they process information and make decisions in daily life (Green, 2015). This progression of student thinking will require a coordinated effort among CSD faculty members to ensure that students receive ample practice for the development of critical thinking skills and dispositions. Green (2015) stated that critical thinking works against energy efficient thought operations. Thus, students need to achieve mastering of thinking skills so that they perceive the purpose of advanced development of these skills. This disposition will help students recognize that better critical thinking skills are tools for better life decisions and problem solving. In addition, CSD students need to recognize that these same skills will help them make better clinical decisions (Apel, 2011; Finn, 2011; Kamhi, 2011). When students recognize the connections between their critical thinking skills and client improvement, it seems logical that they would have more internal motivation to develop the aptitude and disposition for critical thinking

In the clinical professions, pedagogical methods such as problem-based learning, team-based learning, case presentations, and a variety of mapping activities have been suggested as tools for helping students develop critical thinking skills (Day \& Williams, 2000; Dochy, Segers, Van den Bossche, \& Gijbels, 2003; Johnstone \& Otis, 2006; Leahy, Dodd, Walsh, \& Murphy, 2006; Mok, Whitehill \& Dodd, 2008; Tiwari et al. 2006; West, Pomeroy, Park, Gerstenberger, \& Sandoval, 2000). Other research indicates that the pedagogical tools to use may differ at different stages in the students' academic development. Elliott and Hennessey (2001) described differences in learning styles exhibited by students at the beginning and end of communication disorders study that may reflect development of critical thinking skills. They found that students' learning strategies shifted from what they termed 'surface' to 'achieving'. The achieving learning strategy was considered to be better for the flexible thinking needed to be successful in providing clinical services as a communication disorders professional. However, Elliott and Hennessey (2001) used a questionnaire on the students' perceptions of their studying habits and motivations so they did not assess the thinking strategies used by the students. Thus, the authors made assumptions about the students' strategies rather than directly assess them. Nevertheless, when students change their learning strategies then the classroom activities they complete should change to best challenge them to enhance their thinking skills (Byrne \& Dunbar, 2014). 
Pedagogical Techniques for Teaching Critical Thinking Skills. In clinical programs, case presentations and case simulations have been used in problembased and team-based learning activities, with the instructor presenting a clinically based problem that the students solve. The instructor answers questions and provides encouragement as the students work through the problem (Ginsberg, Friberg, \& Visconti, 2012). The presentation of the case studies should be studentcentered and posed in a manner that the students can connect the situations to their current level of learning and their professional aspirations (Ginsberg, et al., 2012). One such structure (Taylor \& Miflin, 2008) includes:

1) A problem is posed first, with no specific student preparation necessary preceding the presentation of the problem.

2) Students activate/articulate existing knowledge as the starting point of discussion in the problem-solving process.

3) Students engage in systematic reasoning about the problem, including applying new learning (p. 756).

McInerney and Fink (2003) described the steps involved in team-based learning with the fourth and fifth steps receiving feedback and no grade as a tool to focus the students thinking on the project:

1) Students learn about the topic through readings, lectures, or videos.

2) Students complete an evaluation on the material individually.

3) Students complete the same evaluation in groups.

4) Instructor then provides additional materials and discussions so that the students can correct thinking errors from the material.

5) Student groups are assigned application projects based on the material that was learned.

6) Student groups are assigned a final, more challenging projects on the topic.

Each student's grade is determined from a combination of the individual and group scores. Part of the grade on the final group project comes from each individual student's contribution to the final project submission. McInerney and Fink (2003) reported that team-based learning led to a variety of positive learning outcomes and enhanced student engagement.

Meta-analyses indicate that problem-based learning is more effective than didactic presentations in the development of psycho-motor, affective, and cognitive skills, and better learning of clinical skills (Prosser \& Sze, 2014; Shin \& Kim, 2013). These studies also show that problem-based learning activities result in enhanced retention of what was learned. However, these interpretations of the effectiveness of the teaching methods may be problematic because the method of assessing the learning and retention of knowledge and skills may differ between the teaching 
methods (Ho, Whitehill, and Ciocca (2014). Instructors need a different set of skills for problem-based learning in contrast to traditional content presentation (Slattery \& Douglas, 2014; Taylor \& Miflin, 2008). Problem-based learning is most effective when instructors receive training for this pedagogical technique (Jung, Tryssenaar, \& Wilkins, 2005).

Problem-based learning may not always be the best choice for an instructor. For example, graduate nursing students exhibited greater development of the skills after completing courses using problem-based learning than did undergraduate students who completed similar courses (Shin \& Kim, 2013). Thus, a foundation of both content specific knowledge and critical thinking skills may be needed for problembased learning activities to be most effective. In addition, instructors should be aware that students often have difficulty grasping the purpose of problem-based learning activities; therefore, the instructor needs to invest time explaining how problem-based learning works in order to make the course effective (Prosser \& Sze, 2014).

Mapping - Visual Displays of Learning. The structure of thinking that students' use in problem-based learning activities can be depicted through visual displays such as mapping. As reported by Davies (2011), these visual displays can enhance the learning of complex relationships that can be present in data sets (Vekiri, 2002; Winn, 1991). Effective visual data displays can create a context in which the learner can simultaneously retain visual and verbal reports of the information in a manner called conjoint retention (Davies, 2011; Kulhavey, Lee, \& Caterino, 1985; Schwartz, 1988). Thus, visual displays that map ideas can be useful tools for students to use when learning the critical thinking skills and dispositions needed to become effective speech-language pathologists and audiologists. However, not all displays are equally effective as teaching tools, and none of them are effective for all types of information or all contexts. Davies (2011) cautions that educators need to use the visual display tool that best fits the objectives of the course. Like problem-based learning, the development of maps to illustrate conceptual patterns and connections need to be explained in order for students to learn from the process of using them (Ambrose, Bridges, DiPietro, Lovett, \& Norman, 2010).

The map can be a thought map, concept map, or argument map. Davies (2011) described the different natures and purposes of these maps. Thought or mind maps are ways of depicting the associations between concepts relevant to a topic (See Figure 2). They generally have a single concept that is at the center of the map with associated concepts and ideas positioned around the central concept. Details about the associated concepts can be connected to them. However, the links in mind maps should be limited to simple associations, otherwise these maps can become overly 
complex. Davies (2011) stated that thought maps are inconsistent in the level of detail and that they poorly represent complex and hierarchical relationships among concepts.

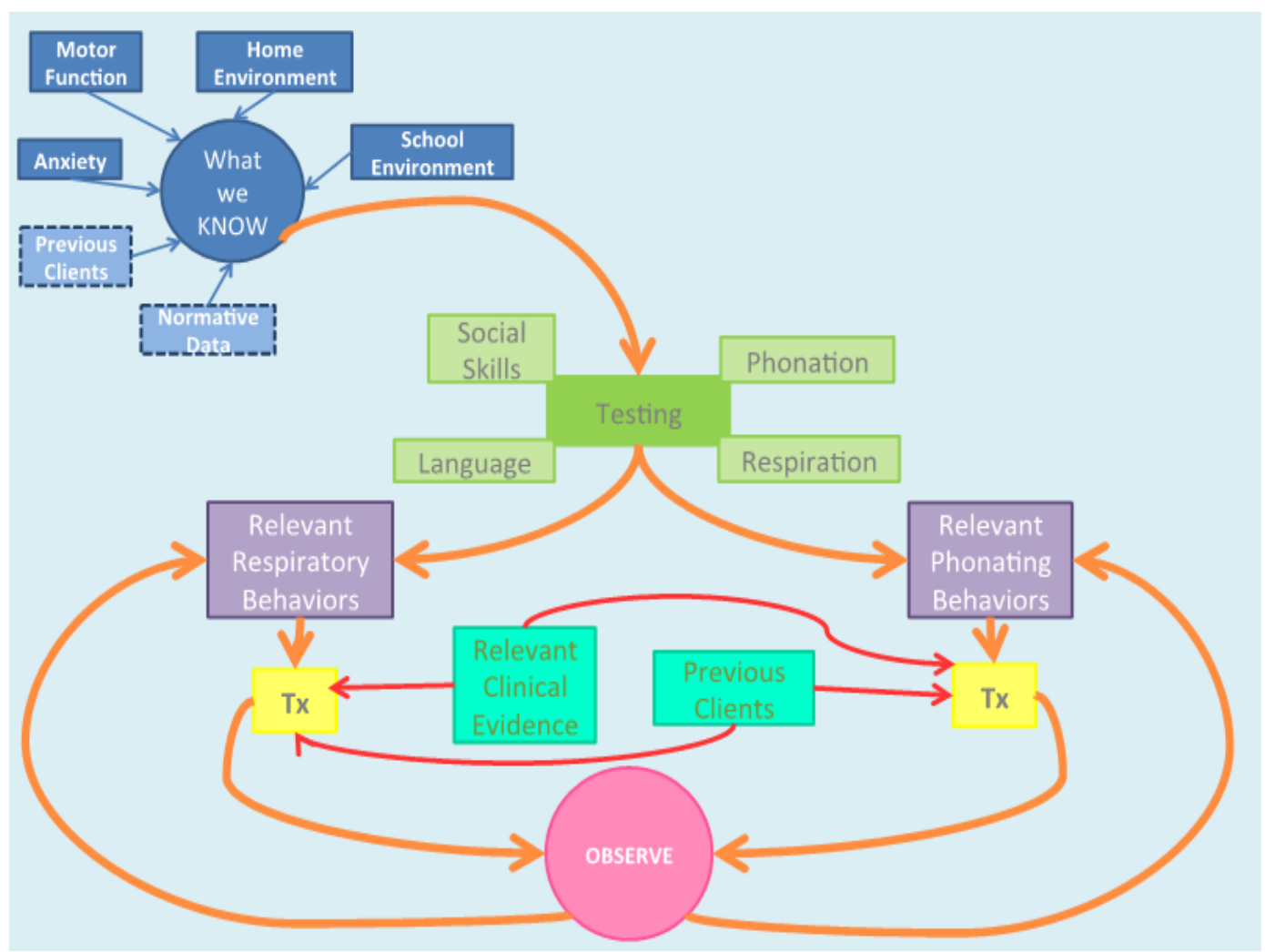

Figure 2. Thought or mind map of what is known and what needs to be determined when preparing to evaluate a client.

Concept maps have a hierarchical "tree" structure that begins with the topic to be addressed that is the focus of the map (Davies, 2011). These maps are considered to be more structured and less pictorial than mind maps (Davies, 2011). The concepts relevant to the topic are arrayed hierarchically with the concepts in levels. Lines between the concepts indicate the relationships among them either horizontally within a level or vertically between layers (Davies, 2011). These lines often have labels on the lines to specify the relationships. Items in each layer are considered to be equal in importance to the topic and in sequence of importance from top to bottom. Concept maps help students create links between new concepts and their existing knowledge (See Figure 3). Problems with concept maps include their complexity and that they do not indicate the relative importance of concepts within a level of the hierarchy (Davies, 2011). 


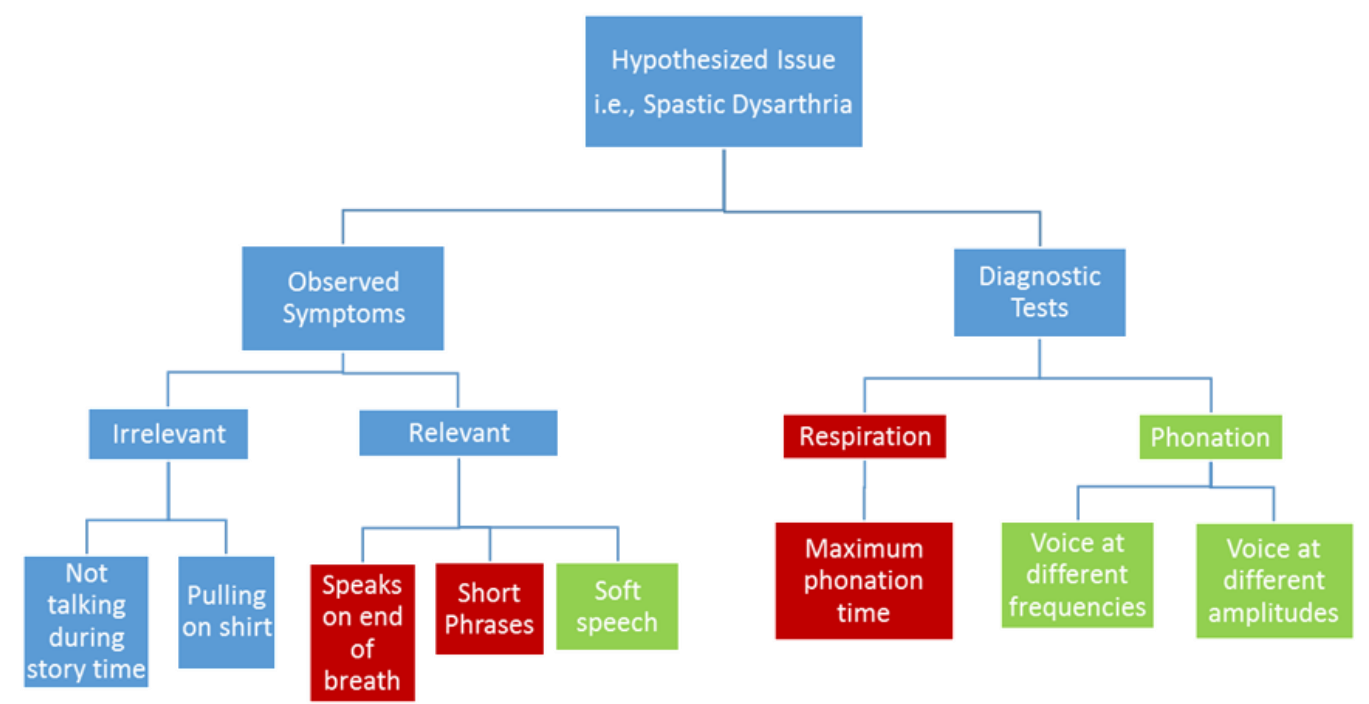

Figure 3. Concept map of what is known and what needs to be determined when preparing to evaluate the same client as shown in the thought map in Figure 2.

Davies (2011) stated that argument maps are the most structured and depict the assumptions, data, and conclusions that comprise the inferential structure of the thinking on a topic (see Figure 4). He said that the top level in these maps is the topic in the form of a proposition, conclusion, or claim being made. The next level is comprised of the supporting assertions for the proposition and objections to it. The level below that consists of the more specific assertions and rebuttals to the assertions and objections in the previous levels. The lowest level consists of the evidence, data, statistics, etc. that support the assertions and rebuttals in the previous levels. Argument maps help students structure the logical inferences between concepts and restricts the inferences to those that can be supported (Davies, 2011). However, argument maps cannot depict more tangential relationships for which data are needed. Thus, the three types of maps can be used to depict one topic at three levels of thinking and understanding, relevant associations from a thought map, relevant relationships at varying levels from a concept map, and relevant arguments and supporting data from an argument map. 


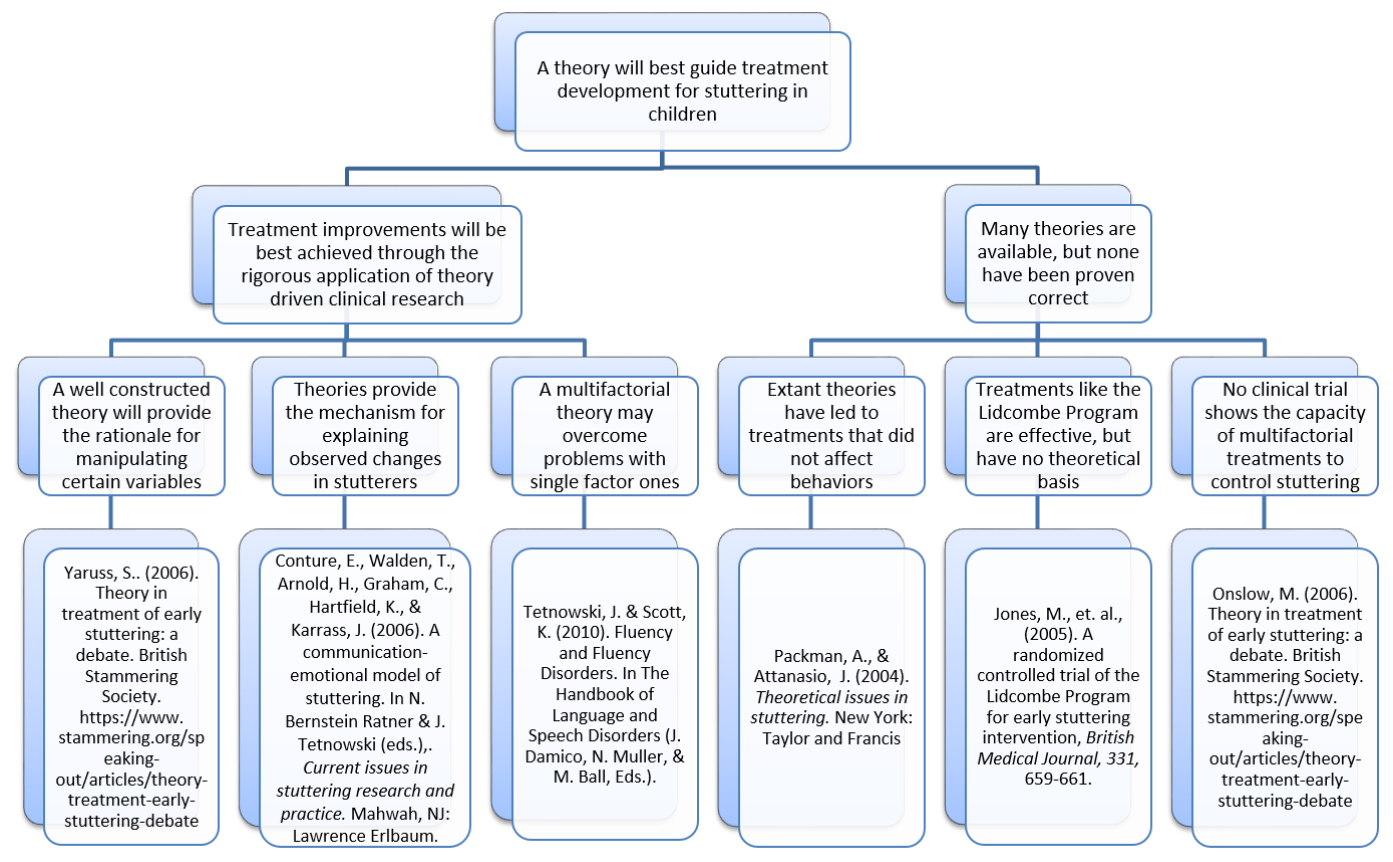

Figure 4. Argument map of the need for theory in developing treatment strategies for young children who stutter.

Using case presentations and simulations in conjunction with mapping activities can provide opportunities for students to perceive their learning as a process of seeking and constructing their understanding of the material rather than merely memorizing or reproducing presented information. This type of learning is slower and requires the students to learn from the errors they make along the way. Thus, students need to have repeated opportunities doing the same task or variations of the task so that they can demonstrate deeper and more complete understanding of both the concept and the process.

When teaching critical thinking skills there is a need to recognize that repeated exposure will be necessary for students to develop the disposition to use these skills when confronted with problems and challenges. Acquiring critical thinking skills and knowledge are necessary, but not sufficient for students to develop the disposition to routinely use the knowledge and skills; they need to be directed to learn the clinical function of consistently applying the skills so they can develop the disposition (Thomas \& Lok, 2015) and retain it across their professional careers.

\section{References}

Abrami, P., Bernard, R., Borokhovski, E., Wade, A., Surkes, M., Tamim, R., \& Zhang, D. (2008). Instructional interventions affecting critical thinking skills 
and dispositions: A stage 1 meta-analysis. Review of Educational Research, 78 (4), 1102-1134.

Abrami, P., Bernard, R., Borokhovski, E., Waddington, D., Wade, A., \& Persson, T. (2015). Strategies for teaching students to think critically: A meta-analysis. Review of Educational Research, 85 (2), 275-314.

ACT Inc. (2000). The Collegiate Assessment of Academic Proficiency-Critical Thinking Test. Iowa City, IA: ACT Inc.

Ambrose, S., Bridges, M., DiPietro, M., Lovett, M., \& Norman, M. (2010). How learning works: Seven research-based principles for smart teaching. San Francisco, CA: Jossey-Bass.

Apel, K. (2011). Science is an attitude: A response to Kamhi. Language, Speech, and Hearing Services in Schools, 42, 65-68.

Arum, R., \& Roksa, J. (2011). Academically adrift. Chicago, IL: University of Chicago Press.

Bailin, S., \& Battersby, M. (2015). Teaching critical thinking as inquiry. In M. Davies \& R. Barnett (Eds.), The Palgrave handbook of critical thinking in higher education (pp. 123-138). New York, NY: Palgrave MacMillan.

Bell, R., \& Loon, M. (2015). The impact of critical thinking dispositions on learning using business simulations. The International Journal of Management Education, 13, 119-127. doi: 10-1016-j.ijme.2015.10.013

Bernard, R. M, Zhang, D., Abrami, P. C, Sicoly, F., Borokhovski, E., \& Surkes, M. A. (2008). Exploring the structure of the Watson-Glaser Critical Thinking appraisal: One scale or many subscales? Thinking Skills and Creativity, 3, 1522.

Beyer, B. K. (1987). Practical strategies for the teaching of thinking. Boston, MA: Allyn and Bacon.

Bloom, B., Engelhart, M., Furst, E., Hill, W., \& Krathwohl, D. (1956). Taxonomy of education objectives: The classification of education goals handbook 1: Cognitive domain. New York, NY: David McKay. 
Burke, B. L., Sears, S. R., Kraus, S., \& Roberts-Cady, S. (2013). Critical analysis: A comparison of critical thinking changes in psychology. Teaching of Psychology, 41(1), 28-36.

Butler, H. (2012). Halpern Critical Thinking Assessment predicts real-world outcomes of critical thinking. Applied Cognitive Psychology, 26, 721-729.

Butler, H., Dwyer, C., Hogan, M., Franco, A., Rivas, S., Sairz, C., \& Almeida, L. (2012). The Halpern Critical Thinking Assessment and real-world outcomes: Cross-national applications. Thinking Skills and Creativity, 7, 112-121.

Byrne, J. \& Dunbar, K. (2014). The nature and development of critical-analytic thinking. Educational Psychology Review, 26, 477-493. doi: 10.1007/s10648014-9284-0.

Council for Aid to Education. (2004). The Collegiate Learning Assessment Test. Available at http://www.cae.org/content/pro_collegiate.htm.

Davies, M. (2011). Concept mapping, mind mapping and argument mapping: What are the differences and do they matter? Journal of Higher Education, 62, 279301.

Davies, M. (2013). Critical thinking and the disciplines reconsidered. Higher Education Research \& Development, 32(4), 529-544. doi: $10.1080 / 07294360.2012 .697878$

Davies, M. \& Barnett, R. (2015). Part II. Teaching critical thinking. In M. Davies $\&$ R. Barnett (Eds.), The Palgrave handbook of critical thinking in higher education (pp. 89-92). New York, NY: Palgrave MacMillan.

Day, R. A., \& Williams, B. (2000). Development of critical thinking through problem-based learning: A pilot study. Journal on Excellence in College Teaching, 11, 203-226.

Dochy, F., Segers, M., Van den Bossche, P., \& Gijbels, D. (2003). Effects of problem-based learning: A meta-analysis. Learning and Instruction, 13, 533568.

Dollaghan, C. (2007). The Handbook for Evidence-Based Practice in Communication Disorders. Baltimore, MD: Brookes. 
Elliott, J., \& Hennessey, N. (2001). Scratching the surface: Speech and Hearing Science students and their approach to learning. In A. Herrmann, \& M. M. Kulski (Eds.), Expanding Horizons in Teaching and Learning. Proceedings of the 10th Annual Teaching and Learning Forum, 7-9 February 2001. Perth, Australia: Curtin University of Technology [Electronic version]. Retrieved August 6, 2013, http://lsn.curtin.edu.au/tlf/tlf2001/elliott.html

Ennis, R. H. (1989). Critical thinking and subject specificity: Clarification and needed research. Educational Researcher, 18 (3), 4-10.

Ennis, R. H., \& Millman, J. (1985). Cornell Critical Thinking Test, Level X. Pacific Grove, CA: Midwest Publications.

Ennis, R., \& Weir, E. (1985). The Ennis-Weir Critical Thinking Essay Test. Pacific Grove, CA: Midwest Publications.

Facione, P. (1990). The California Critical Thinking Skills Test: College level: Interpreting the CCTST, group norms and sub-scores (Technical Report No. \#4). Millbrae, CA: California Academic Press.

Facione, P., Facione, N., \& Giancarlo, C. (1996). The California Critical Thinking Disposition Inventory. Millbrae, CA: California Academic Press.

Finn, P. (2011). Critical thinking: Knowledge and skills for evidence-based practice. Language, Speech, and Hearing Services in Schools, 42, 69-72.

Ginsberg, S. M., Friberg, J. C., \& Visconti, C. F. (2012). Scholarship of teaching and learning in speech-language pathology and audiology: Evidence-based education. San Diego, CA: Plural Publishing.

Green, P. (2015). Teaching critical thinking for lifelong learning. In M. Davies \& R. Barnett (Eds.), The Palgrave handbook of critical thinking in higher education (pp. 107-121). New York, NY: Palgrave MacMillan.

Grillo, E., Koenig, M., Gunter, C., \& Kim, S. (2015). Teaching CSD graduate students to think critically, apply evidence and write professionally. Communication Disorders Quarterly, 36(4), 241-251.

Gunter, C., \& LeJeune, J. B. (2015). Critical thinking in clinical practice in speechlanguage pathology. Dubuque, IA: Kendall Hunt Publishing. 
Halliday, J. (2000). Critical thinking and the academic vocational divide. The Curriculum Journal, 11(2), 159-175, DOI: 10.1080/09585170050045182

Halpern, D. F. (2010). Halpern Critical Thinking Assessment. Schuhfried (Vienna Test System). Retrieved from http://www.schuhfried.at

Ho, D., Whitehill, T., \& Ciocca, V. (2014). Performance of speech-language pathology students in problem-based learning tutorials and in clinical practice. Clinical Linguistics \& Phonetics, 28(1-2), 83-97. doi: 10.3109/02699206.2013.812146

Johnstone, A. H., \& Otis, K. H. (2006). Concept mapping in problem based learning: A cautionary tale. Chemistry Education Research and Practice, 7, 84-95.

Jones, A. (2015). A disciplined approach to critical thinking. In M. Davies \& R. Barnett (Eds.), The Palgrave handbook of critical thinking in higher education (pp. 169-183). New York, NY: Palgrave MacMillan.

Jung, B., Tryssenaar, J., \& Wilkins, S. (2005). Becoming a tutor: Exploring the learning experiences and needs of novice tutors in a PBL programme. Medical Teacher, 27:7, 606-612. doi: 10.1080/01421590500069728

Kamhi, A. G. (2011). Balancing certainty and uncertainty in clinical practice. Language, Speech, and Hearing Services in Schools, 42, 59-64.

Kida, T. (2006). Don't believe everything that you think: The 6 basic mistakes we make in thinking. Amherst, NY: Prometheus Books.

Kulhavey, R., Lee, J., \& Caterino, L. (1985). Conjoint retention of maps and related discourse. Contemporary Educational Psychology, 10, 683-699.

Leahy, M. M., Dodd, B. J., Walsh, I. P., \& Murphy, K. (2006). Education for practice in the UK and Ireland: Implementing problem-based learning. Folia Phoniatrica et Logopaedica, 58, 48-54.

Macpherson, K., \& Owen, C. (2010). Assessment of critical thinking ability in medical students, Assessment \& Evaluation in Higher Education, 35(1), 4154, DOI:10.1080/02602930802475471 
McInerney, M., \& Fink, L. D. (2003). Team-based learning enhances long-term retention and critical thinking in an undergraduate microbial physiology course. Microbiology Education, 3, 3-12.

McPeck, J. (1981). Critical thinking and education. New York, NY: St. Martin's Press.

Mok, C., Whitehill, T., \& Dodd, B. (2008). Problem-based learning, critical thinking and concept mapping in speech-language pathology education: A review. International Journal of Speech-Language Pathology, 10(6). 438448.

Morris, R., Bishop, M., Scholz, K., \& LaPointe, L. (Submitted). Development and Initial Analysis of a Content Specific Assessment of Critical Thinking: Critical Thinking in Communication Sciences and Disorders. Communication Disorders Quarterly.

Orlikoff, R., Schiavetti, N., \& Metz, D., (2015). Evaluating research in communication disorders ( $7^{\text {th }}$ ed.). Boston, MA: Pearson Education, Inc.

Paul, R. \& Elder, L. (2001). Critical Thinking: Tools for Taking Charge of Your Learning and Your Life. Upper Saddle River, NJ: Prentice Hall.

Possin, K. (2008). A field guide to critical-thinking assessment. Teaching Philosophy, 31:3, 201-228.

Prosser, M., \& Sze, D. (2014). Problem-based learning: Student learning experiences and outcomes. Clinical Linguistics \& Phonetics, 28(1-2), 112123. doi: 10.3109/02699206.2013.820351

Royalty, J. (1995). The generalizability of critical thinking: Paranormal beliefs versus statistical reasoning. Journal of Genetic Psychology, 156(4), 477-488.

Sá, W. C., West, R. F. \& Stanovich, K. E. (1999). The domain specificity and generality of belief bias: Searching for a generalizable critical thinking skill. Journal of Educational Psychology, 91(3), 497-510. doi: 10.1037/00220663.91.3.497

Schwartz, N. (1988). Cognitive processing characteristics of maps: Implications for instruction. Educational and Psychological Research, 8, 93-101. 
Shin, I.-S., \& Kim, J.-H., (2013). The effect of problem-based learning in nursing education: A meta-analysis. Advances in Health Science Education, 18, 11031120. doi 10.1007/s10459-012-9436-2

Slattery, J. \& Douglas, J. (2014). An exploration of novice and experienced problem-based learning facilitators' perceptions of their roles in a speechlanguage pathology programme. Does experience matter? Clinical Linguistics \& Phonetics, 28(1-2), 24-35, doi: 10.3109/02699206.2013.816781

Smith, G. (2002). Are there domain-specific thinking skills? Journal of Philosophy Education, 36(2), 207-227. doi: 10.1111/1467-9752.00270

Stein, B., \& Haynes, A. (2011). Engaging faculty in the assessment and improvement of students' critical thinking using the Critical Thinking Assessment Test. Change: The Magazine of Higher Learning, 43:2, 44-49. doi: 10.1080/00091383.2011.550254

Stein, B., Haynes, A., \& Redding, M. (2007). Project CAT: Assessing critical thinking skills. In D. Deeds \& B. Callen (Eds.) Proceedings of the National STEM Assessment Conference (pp. 290-299). Washington, DC: NSF \& Drury University.

Taylor, D., \& Miflin, B. (2008). Problem-based learning: Where are we now? Medical Teacher, 30(8), 742-763.

Thomas, K., \& Lok, B. (2015). Teaching critical thinking: An operational framework. In M. Davies \& R. Barnett (Eds.), The Palgrave handbook of critical thinking in higher education (pp. 93-105). New York, NY: Palgrave MacMillan.

Tiwari, A., Chan, S., Wong, E., Wong, D., Chui, C., Wong, A., \& Patil, N. (2006). The effect of problem-based learning on students' approaches to learning in the context of clinical nursing education. Nurse Education Today, 26, 430438 .

United States Deaprtment of Education. (2006). A Test of Leadership: Charting the Future of U.S. Higher Education. Washington, DC: ED Pubs. Downloaded 02/08/2016 from https://www2.ed.gov/about/bdscomm/list/hiedfuture/ reports/final-report.pdf 
Vekiri, I. (2002). What is the value of graphical displays in learning? Educational Psychology Review, 14(3), 261-313.

Wagner, T. \& Harvey, R. (2006). Development of a new critical thinking test using item response theory. Psychological Assessment, 18(1), 100-105. DOI: 10.1037/1040-3590.18.1.100

Watson, G., \& Glaser, E. M. (1980). Watson-Glaser Critical Thinking Appraisal. San Antonio, TX: PsychCorp.

Wendland, M., Robinson, C., \& Williams, P. (2015). Thick critical thinking: Toward a new classroom pedagogy. . In M. Davies \& R. Barnett (Eds.), The Palgrave handbook of critical thinking in higher education (pp. 153-168). New York, NY: Palgrave MacMillan.

West, D. C., Pomeroy, J. R., Park, J. K., Gerstenberger, E. A., \& Sandoval, J. (2000). Critical thinking in graduate medical education: a role for concept mapping assessment? Journal of American Medical Association, 284, 11051110.

Winn, W. (1991). Learning from maps and diagrams. Educational Psychology Review, 3(3), 211-247.

Yuan, S.-P., Liao, H.-C., Wang, Y.-H., \& Ming-Jen Chou, M.-J. (2014). Development of a scale to measure the critical thinking disposition of medical care professionals. Social Behavior and Personality, 42(2), 303-312 doi: 10.2224/sbp.2014.42.2.303 